\title{
The Effect of Fiscal Policy on Capital Flight in Namibia
}

\author{
Valdemar J. Undji, Teresia Kaulihowa \\ University of Namibia, Windhoek, Namibia \\ vundji@yahoo.com, teeza.kaulihowa@gmail.com
}

\begin{abstract}
The occurrences of capital flight continue to be of great concern for many developing countries and Namibia is not an exception to this. This study aimed at examining the effect of fiscal policy on capital flight in Namibia for the period, 2009-2018. To assess this, the Auto-Regressive Distributive Lag (ARDL) bound test to cointegration technique was employed. The finding revealed that there is a long-run relationship between the selected macroeconomic factors and capital flight. In particular in the long-run government expenditure and its interaction with debt stock are found to positively affect capital flight. In the short-run however, past capital flight, previous period tax rates, previous external debt, current debt stock, previous inflation rate, as well as previous financial deepening were found to bear a positive effect on capital flight. Estimate of capital flight using the residual approach shows that Namibia lost about $\mathrm{N} \$ 42$ billion in 9 years through capital flight. This means on average Namibia lost close to $\mathrm{N} \$ 5$ billion in capital flight. These empirical findings, call for serious policy interventions in order to minimize and contain the issue of capital flight in the country.
\end{abstract}

Keywords: Capital Flight, Fiscal Policy, ARDL, Namibia.

\section{Introduction}

Background to the Study: Empirical literature characterises the late periods of 1970s and 1980s as years of abject debt crisis and huge capital flight. Some Latin America countries (such as, Mexico, Argentina, Venezuela and Uruguay) experienced persistent uncertain macroeconomic conditions at the time (Muchai \& Muchai, 2016; Okoli, 2008; Le \& Zak, 2006; and Mohamed \& Finnoff, 2005) and in order to avert these catastrophes, the countries affected deemed it necessary to deploy much focus on how they handled their fiscal policy instruments. Policy measures that achieved to curb the outflows of funds by domestic residents were thus implemented. One of the major root causes of slower domestic investment, which might be responsible for staggering economic development for most developing and emerging economies, is hypothesized to result from capital flight (Okoli, 2008). Various economists have defined the phenomenon of capital flight rather differently, depending on what they aim to achieve. This study defines capital flight as the movement of financial assets due to perceptions that these assets face an unusual level of financial risk if they are domestically retained (Cooper \& Hardt, 2000). Theoretical literatures offer more than one method of measuring capital flight. This is due to differences in the way in which different authors choose to define this phenomenon. The following measuring techniques are generally debated within the literatures: most notably, the Residual Method, the Morgan Guaranty Method, the Hot Money Method, the Dooley Method, the Trade Miss Invoicing Method, and the Asset Method.

Despite the variations in the way capital flight is measured, this study employs the Residual Method to calculate capital flight in Namibia. This approach is primarily suitable as it is straight forward to employ and because it is difficult for one to establish whether the amounts for capital flight could be utilised in a more productive and beneficial way. The issue of capital flight is of great concern to the African continent and it is believed to be amongst the leading factors deterring the continent's much need development. Kar and Spanjers (2014) revealed that between period 2003- 2012 the Sub-Saharan African region, consisting of 48 countries, lost US $\$ 528.9$ billion in the form of capital flight. The loss represented $35.7 \%$ of their combined GDP in the year 2012. With regards to Namibia, the accumulated amount for illicit capital outflows between 2003- 2012 was estimated at US\$ 6032 million. In comparison to other member countries of the Common Monetary Area, Namibia is ranked second (in terms of capital flight) to South Africa, followed by Swaziland and Lesotho (Allum et al., 2008). The loss of capital is absolutely deplorable to Namibia's economy as it impedes the much needed level of investment that would assist the country to attain its desired growth and developmental targets stipulated in the various National Development Plans - the documents which serve as the blue print towards industrialisation by the year 2030. Besides this, it is also suspected that Namibia's pursuit for an expansionary fiscal policy over the past years might have well contributed to capital flight. In 
general, fiscal policy is refers to adjustments by the government on its levels of spending and taxation in order influence a country's economy.

In essence, a sound fiscal policy is vital in order to promote price stability and sustain growth of the economy. Since attaining independence in 1990, the Namibian government has been struggling to increase its revenues collection such that it outweighs its expenditures, mainly because of its narrow tax base and the recent shortfalls in the SACU revenue receipts. For instance, the total expenditure outturn for 2010/11 financial year was $\mathrm{N} \$ 27.3$ billion, but by the year $2016 / 17$ it stood at $\mathrm{N} \$ 62.3$ billion. The corresponding total revenue collection was $\mathrm{N} \$ 23.4$ billion and $\mathrm{N} \$ 50.9$ billion in 2010/11 and 2016/17 respectively. As a result of the imbalances in revenues and expenditure, government has been exploiting the option of continuous borrowing from both domestic and foreign sources to finance its budget deficit. In 1992 the combined outstanding domestic and external debt was N\$ 786.2 million. By the year 2009, the total debt stock stood at N\$ 11.6 billion due to deficit financing of its budget. From 2009 to 2018 the debt stock amount increased from N\$ 11.6 billion to $\mathrm{N} \$ 86.7$ billion, respectively. Meaning in a space of 9 years, the level of debt stock grew by approximately $646 \%$. In fact, recent data for Namibia shows that total debt as a percentage of GDP stood at $46.3 \%$ in $2018 / 19$ financial year, which is above the 35\% bench mark, as compared to $16.6 \%$ in 2010 . Namibia is reputably known for its high level of domestic saving; however, it is also characterised by high capital flight (Ogbokor \& Musilika, 2014). Moreover, it diverge a country's savings away from funding real domestic investment. It also negatively affects the country's balance of payment.

Capital flight can be detrimental to any economy in many ways; namely, the loss of funds through capital flight minimizes the domestic tax base by affecting the redistribution of income. In spite of the unwanted implications of capital flight, empirical literatures that examine how fiscal policy (such as its tax rate, external debt, government spending and etcetera) affects capital flight do not exist for Namibia. Whenever the effect of fiscal policy on capital flight is left unexamined, it is likely to jeopardise government efforts in addressing its development agenda. This study therefore is highly crucial for Namibia, especially now that the country has entered into a period of stringent fiscal consolidation. The contribution of this study is uniquely to the Namibian sphere and it is indispensable for a country that is believed to suffer from massive capital flight. It is against this background that this study will not merely examine the effect that fiscal policy has on capital flight, but it will as well propose how best the fiscal policy tools can be used to curb and mitigate the problem, thereby boosting government revenues, enhancing the welfare of societies and that of the entire economy. This paper contributes uniquely to literature by addressing the following specific objectives;

- To evaluate the relationship between the fiscal variables and capital flight.

- To test for the long-run and short-run relationship between the selected macroeconomic variables and capital flight.

The rest of the paper is organised as follows: the section which hereafter covers the literature review. Section 3 discusses the methodology. The empirical findings are presented in section 4 and section 5 concludes the study.

\section{Literature Review}

Theoretical Literature: According to Wujung and Mbella (2016) and Henry (2013), there are four main theories related to capital flight: Namely, a) the investment diversion theory, b) the debt-driven theory also known as debt overhang theory, c) the tax depressing theory and d) the austerity generation theory.

The Investment Diversion Theory: The investment diversion theory stipulates that there are two factors that give rise to capital flight; namely, the macroeconomic and political uncertainties in developing countries as well as better returns on investment activities in advanced economies. Better investment opportunities are brought about by a high return on investment abroad, a variety of financial instruments to invest in, a political and economic stability, an amicable tax regime system (i.e. lower taxes or tax exemption), and concealment of accounts in tax haven countries. The argument of favourable tax climate seems to suggests that countries would be better off, in terms of capital flows, had they framed their tax policies towards a lower or even a tax-free system. However, Muchai and Muchai (2016) cautioned that lowering tax and offering tax incentives in order to attract or retain capital causes market distortions and tax favouritism, 
which in turn lead on to further capital losses. What is more aggravating is that in the eve of tax break uplift, international capital repatriate their funds to regions that have a favourable tax regime. The persistent increase in the levels of capital flight exerts a negative effect on a country's economic development. This is so that they avoid paying high taxes, and in the same instance contributing to a country's capital flight. The consequences of these actions are: a decrease in the overall investment, low economic growth which in turn causes the level of unemployment to rise, thereby increasing the dependency ratio and the level of poverty.

The Debt Driven or Debt Overhang Theory: The debt driven theory is simply an extension of the investment diversion theory. This theory propagates external debt as a catalyst for capital flight. It advocates that in the event of a country's huge external debt, residents tend to smuggle their financial resources outside the country. Furthermore, the theory postulates that capital flight discourages people from saving and investing since it leads to a devaluation of the domestic currency, a rise in fiscal instability and expropriation of assets for debt repayments (Wujung \& Mbella, 2016). Therefore, any attempt by the central bank to hedge its currency from being devaluating will only leads to further losses in the levels of its foreign reserves.

The Tax Depressing Theory: The tax depressing theory stipulates that capital flight causes a significant loss of government tax revenue. This is to say that government has no power whatsoever to tax the wealth held abroad by its domestic residents since it is beyond their control. This potentially diminishes government's capacity to service its debt, thereby increasing the debt burden which limits economic growth and development. By all means, it implies that capital flight cripples government revenue generating power.

The Austerity Theory: The austerity thesis can be described as strict fiscal stance by the government aimed at narrowing its debt and budget deficit. Persistent deficit spending have far-reaching repercussions since it causes distortions in the taxes system for most developing economies by, for instance, increasing the expected tax rates; thereby, leading to capital flight (see Ndikumana \& Boyce, 2003). In order to attain a narrow debt and budget deficit, austerity measures, like a decrease in government spending or rise in taxes, are put in place in order to align government revenues closer to the expenditures. The resultants of these harsh measures are obviously not without controversies. In fact, those against it often contend that austerity measure lowers economic growth and development. Moreover, it increases the level of Gini-coefficient (gap between the rich and the poor), thereby creating an unequal distribution of wealth in the country. In simpler terms, the austerity thesis observes the poor being dragged into further debts because of the hostile policies, such as high taxes, adopted to service the debt obligations from the international financial markets.

Empirical Literature: There is a considerable volume of empirical literature emanating from the developing nations with regards to capital flights and its probable determinants exist. However, it is not without ambiguities. Kollamparambil and Gumbo (2018) conducted a study to examine the macroeconomic and institutional determinants of capital flight using panel data for 29 Sub-Saharan African Countries from 19962010. Upon applying the Arellano-Bover/Blundell- Bond System GMM dynamic estimator, the tests results revealed that external debt, inflation and economic growth were found to be key determinants of capital flight. Similarly, Muchai and Muchai (2016) examined the relationship between fiscal policy and capital flight in Kenya using annual time series data between the period 1970 to 2010; the ARDL bounds test for cointegration was applied and the findings revealed that previous capital flight, change in debt stock, and government expenditure had no significant effect on capital flight. Nevertheless, external debt, taxation, and expenditure practices taken under different political regimes are found to have a substantial effect (External debt and taxation had positive affected whereas expenditure practices was found to be negative) on capital flight. Likewise, Ndiaye and Siri (2016) employed the instrumental variable-two stages least squares technique in order to establish the determinants of capital flight in Burkina Faso between periods 1970 to 2012. Their findings illustrated that external debts positively affected capital flight.

In the same vein, Ahmad and Sahto (2015), Henry (2013), Al-Fayoumi, AlZoubi, and Abuzayed (2012), Okoli (2008) investigated the determinants of capital flight in Pakistan, Nigeria, Middle East and North Africa (MENA) countries and Nigeria respectively. Their results revealed that a long-run relationship exists between capital flight and the selected determinants (external debt, inflation, amongst others variables) but in the short-run there was no relationship. Whereas the high levels of: fiscal deficits, interest rate, political instability and external debt servicing GDP ratio were found to exacerbate capital flight in Nigeria. 
Correspondingly, supportive evidences with regards to the causes of capital flight in MENA countries were found to mainly being driven by previous capital flight, foreign direct investment, real GDP growth rate, external debt and political uncertainty. The findings are in line with those obtained by Makochekanwa (2007), who carried out a similar study in Zimbabwe and found external debt and foreign direct investment to explain capital flight. Nevertheless, Makochekanwa (2007) found economic growth to be negatively related. Additionally, Le and Zak (2006) also examined the relationship between political uncertainty and capital flight on 45 developing countries over a period of 16 years, by relating capital flight to return differentials, risk aversion, economic risk, political, instability.

Their results revealed political instability as the most important factor to influencing capital flight, and three types of risk were found to be statistically significant in affecting capital flight. Mohamed and Finnoff (2005) estimated the wealth lost as a result of capital flight in South Africa during the period 1980-2000 and found that capital flight as a percentage of GDP was higher after the realisation of the democratic elections in 1994 as opposed to the apartheid era (1980-1993). This finding is in concordance with a study conducted in Kenya by Muchai and Muchai (2016) who found that a change in political regime has a substantial effect on capital flight. In another investigation by Ndikumana and Boyce (2003) in which they uncovered the determinants of capital flight from 30 sub-Saharan African countries, of which 24 of them were categorised of being highly indebted low-income countries, for the period 1970-1996. The results found external debt to be of vitality in determining capital flight, suggesting that capital flight is debt driven. Furthermore, their study divulged that for every dollar borrowed externally, about 80 cents of it escaped in the form of Capital flight in that same year.

On the other hand, the results of fiscal policy indicators turned out to be ambiguous. Lastly, political environment and governance turned out to have a weak explanatory power. These findings agree with those obtained by Hermes and Lensink (2001) who investigated the relationship between the uncertainty of government policies and its influence on capital flight, whose findings illustrated that policy uncertainty, tax payments, government consumption and the inflation rate, proved to be statistically significant with a positive impact on capital flight. It is evident from these discussions that in most cases political uncertainty is a significant root cause of capital flight in many developing countries (Le \& Zak, 2006), Likewise, Muchai and Muchai (2016); Al-Fayoumi, AlZoubi, and Abuzayed (2012), found capital flight to be positively influenced by increase in taxes, high interest rates, lower GDP growth rate, and external debts. This is to say that the fiscal instruments used in these studies support the claim that fiscal policy triggers capital flight.

However, this conclusion contradicts Ndikumana and Boyce (2003) who noted that the results of fiscal policy indicators turned to be ambiguous in nature. Similarly, inflation and lagged capital flight were found to positively explain capital flight by (Ndikumana \& Boyce, 2003) and (Hermes \& Lensink, 2001). Meanwhile, Muchai and Muchai (2016) found these variables to affect capital flight negatively. From the aforementioned empirical literature studies, it is evident that there are mixed findings with regards to the factors that could potentially cause capital flight in a country. This encompasses those that agree to have found a positive relationship, those that obtained a negative relationship to those that did not find any relationship at all amongst the determinants of capital flight. Different empirical studies with different data frequencies in different (or same) countries have employed different methodological approaches. But it has not yet been established where Namibia stands in the midst of this conflicting debates. This study therefore contributes to the literature gap for Namibia as it will establish where the country's position is, amongst these contradictory views.

\section{Research Methodology}

In order to capture the study's objectives, quarterly time series data (1993 to 2014) from Bank of Namibia are utilised. The modelling approach used by Muchai and Muchai (2016) is adopted in this study but with some slight modification on it. The functional linear equation semi-log model is specified as follows:

$K F_{r t}=\beta_{0}+\beta_{1} \ln E D_{t}+\beta_{2} C D_{t}+\beta_{3} \ln T_{t}+\beta_{4} \ln G X_{t}+\beta_{5} \ln G D_{t}+\beta_{6} \ln I N F_{t}+\beta_{7} \ln F D_{t}+\xi_{t}$

Where, $K F_{r}=$ capital flight according to the residual approach is measured as ratio of capital flight to GDP; $E D$ $=$ external debt is measured as ratio of total external debt to GDP; $C D=$ change in debt stock measured as ratio of the change in debt stock to GDP; $T=$ the multiplicative inverse of company tax rates; $G X=$ government 
expenditure measured as ratio of government expenditure to GDP; GD is the interaction term of GX with CD; $I N F=$ average multiplicative inverse of inflation rate; $F D=$ financial deepening measured as ratio of money supply(M2) to GDP; $\xi$ is the stochastic error term possessing its usual properties; $t$ is time, $l n$ represent logarithm and the rest are parameters. The basis for including the variables in the above regression model is presented next:

External Debt (ED): According to the debt driven theory, a rise in levels of external debt propels residents in an economy to transfer their funds abroad. This implies that there is a positive relationship between capital flight and external debt.

Debt Stock (CD): The debt driven theory also stipulates that the more a particular country accumulates its debt stock, the greater the capital flight due to debt serving. Hence, the coefficient of CD is expected to be positive.

Company Taxes Rates (T): In line with the investment diversion theory, an unfavourable tax policy, such as higher taxes on corporate income, diverts investments from unfriendly tax regions to more friendly tax destinations. Therefore, a positive relationship between increase in taxes and capital flight is expected.

Government Expenditure (GX): The Keynes theory of government spending states that an increase in government expenditure enhances economic growth due to the level of employment that is created in the process. It further propagates that an expansionary fiscal spending stimulates the desired growth of a country's economy as well as shielding it from any recessionary pressures. The outcome of increased government spending with regards to capital flight is as follow: Firstly, a boost in the economy's growth guarantees investors' trust, thereby diminishing capital flight. Secondly, it enhances aggregate demand which in turn fosters domestic investment, to which international capital will be attracted. Notwithstanding, in most developing countries deficit spending have caused far-reaching repercussions on their economies. Particularly, a high budget deficit may distort the tax system since it means a rise in the expected tax rates, thereupon leading to capital flight.

Average Inflation (INF): Inflation which is a persistent rise in the general price level of domestic goods and services vis-à-vis foreign price levels results into a faster decline of the real value of domestically held assets as compared to similar assets abroad. Under these circumstances, rational residents hedge their assets against losses by transferring them to countries with least inflation rates (Cuddington, 1986).

Financial Deepening (FD): Not many studies have focussed on the role played by financial intermediation with respect to capital flight. In essence as the degree of the financial sector deepens, capital flight becomes more contained. However, some researchers argue that financial deepening may spur capital flight, especially if it facilitates international capital transfers. This may be the case especially if financial markets are liberalised and international capital movements are deregulated, then domestic capital may be expected to flow abroad provided the risk-returns are greater in those markets (Okoli, 2008). With regards to Namibia, it has experienced some levels of financial deepening as evidenced through improvements in the areas of financial sector service provision, which is well regulated. Hence, a negative relation between financial deepening and capital flight is expected. Subsequent to the discussions above are the a priori expectations of the coefficients of the regression model: $\beta_{1}>0, \beta_{2}>0, \beta_{3}>0, \beta_{4}>0, \beta_{5}>0$, and $\beta_{6}>0$, and $\beta_{7}<0$.

Estimation Techniques: To investigate the effect of fiscal policy on capital flight, this study employed the Auto-Regressive Distributed Lag Bounds Test (ARDL BT) to cointegration technique as developed by Pesaran, Shin, and Smith (2001). This is an advanced approach used to validate the existence (or inexistence) of a longrun association between variables. The ARDL BT possesses numerous advantages as when compared to other cointegration techniques (such as, Engle and Granger and the Johansen and Juselius cointegration approach). One advance of the ARDL BT method is that it can be used irrespective of ambiguities in the order of integration of variables i.e. irrespective of whether they are purely I(0), purely I(1) or a combination of both which is not acceptable under the aforementioned traditional approaches. Another benefit for using the ARDL BT approach is that, it provides better results for studies consisting of a smaller sample size and produces unbiased estimation of the short and long-run parameters simultaneously. 
Besides it being suitable when handling smaller sample sizes, the ADRL BT allows estimations to be carried out even if the explanatory variables being considered are endogenous. That is; it is sufficient to simultaneously correct for residual serial correlation. Before employing the ARDL BT it was crucial that some pre-conditions be satisfied: Firstly, it was necessary to determine the optimum lag length as suggested by various information criteria. The selected optimum lag length was then used in all unit root tests. This requirement ensured the choice of the best long-run equation model and it was necessary in order to have a standard error term that is normally distributed, homoscedastic and without serial correlation. Secondly, the time series properties of the data were examined in order to determine whether or not the data was stationary in levels, thereby determining the order of integration of the variables. The stationarity step is indispensable when dealing with time series data in order to mitigate spurious results.

This study used the Augmented Dickey Fuller (ADF) together with the Kwiatkowski-Phillips-Schmidt-Shin (KPSS) test to check for unit root. The KPSS test was used to check the robustness of the ADF test since it is superior to the ADF test. Thirdly, the ARDL BT to cointegration was estimated. This means, other supportive tests should be carried out in order to reach a conclusion. This was examined under the null hypothesis of no co-integration through a joint significance test of lagged levels of the variable. Letting $\boldsymbol{Z}_{\boldsymbol{t}}$ to represent the capital flight model specified in equation (1) as:

$\mathrm{Z}_{t}=\left(K F_{r t}, \ln E D_{t}, C D_{t}, \ln T_{t}, \ln G X_{t}, \ln G D_{t}, \ln I N F_{t}, \ln F D_{t}\right)$

The selected ARDL (k) long-run reduced-form equation becomes:

$\Delta K F_{r t}=\alpha_{0}+\alpha_{1} K F_{r t-1}+\alpha_{2} \ln E D_{t-1}+\alpha_{3} C D_{t-1}+\alpha_{4} \ln T_{t-1}+\alpha_{5} \ln G X_{t-1}+\alpha_{6} \ln G D_{t-1}+\alpha_{7} \ln I N F_{t-1}+\alpha_{8} \ln F D_{t-1}+\sum_{i=1}^{k} \delta_{i} \Delta Z_{t-1}+\xi_{t} \ldots \ldots . . .(3)$

Where: $\mathrm{k}$ is the optimum lag length as proposed by the various information criterions; $\Delta$ denotes the first difference operator; $\delta$ is the parameter meant to capture the short-run relationship and the rest of the variables are as defined previously.

The null hypothesis of no cointegration amongst is expressed as;

$\mathbf{H}_{0}: \alpha_{1}=\alpha_{2}=\alpha_{3}=\alpha_{4}=\alpha_{5}=\alpha_{6}=\alpha_{7}=\alpha_{8}=0$ (Null, i.e. no long-run relationship).

$\mathbf{H}_{1}: \alpha_{1} \neq \alpha_{2} \neq \alpha_{3} \neq \alpha_{4} \neq \alpha_{5} \neq \alpha_{6} \neq \alpha_{7} \neq \alpha_{8} \neq 0$ (Alternative, i.e. there is a long-run relationship).

The above hypotheses are tested by means of an F-test (Wald test). Pesaran et al. (2001) provides two sets of critical value for different model specifications. The first set assumes that all variables are I (0), entailing no cointegration amongst the underlying variable. The second set assumes that all variables are I (1), implying the existence of cointegration amongst the variables. Based on the sample size of this study (88 observations), this paper finds it appropriate to use the critical value provided in Narayan (2005) and Pesaran, et al. (2001) study. The critical value in Pesaran, et al. (2001) are mostly suitable for larger sample sizes whilst those in Narayan (2005) are based on a relatively smaller sample size of 30-80 observations. Based on the Wald test, if the computed F-statistic for the joint significance lies outside the critical bounds, a final decision regarding cointegration can be reached, without one bothering to know whether the variables are integrated of order I(0) or I(1).

In other words, when the computed F-statistics is larger than the upper bound critical value, then the null hypothesis is rejected, meaning the variables are cointegrated. On the other hand, if F-statistic falls below the lower bound, then the null hypothesis of no cointegration amongst the variables cannot be rejected. However, if the F-statistic lies within the lower and upper bounds, the test is inconclusive. The cointegration property is supported by data hence an error correction model (ECM) is estimated. In this case, the short-run dynamic parameters can be obtained by estimating an error correction model from the long-run estimates. The reduced form short-run model can be specified as:

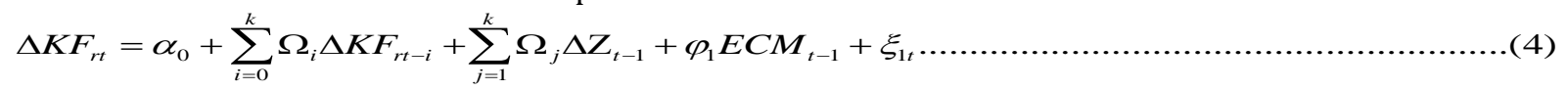

Where, $\Omega_{i}$ measures the short-run dynamics coefficients of the model's convergence to the equilibrium; $\varphi$ measures the speed of adjustment needed for parameters to converge into the long-run equilibrium in the event of shocks in the system; ECM is the error correction term obtained from the estimated equilibrium relationship of equation (3) and the rest of the variables are as previously defined. The model's robustness is 
further determined by checking for autocorrelation, heteroscedasticity, the CUSUM stability test and the normality of residuals.

\section{Empirical Analysis and Results}

Lag Length Selection Test: Before carrying out the ARDL BT to cointegration, the optimum numbers of lags length to be used under unit root test and other subsequent tests needs to be identified. Table 1 below illustrates the test results obtained by various information criterions.

Table 1: Vector Autoregressive Lag Length Selection Criteria

\begin{tabular}{lllllll}
\hline Lag & Log L & LR & FPE & AIC & SC & HQ \\
\hline 0 & 513.7638 & NA & $3.88 \mathrm{e}-23$ & -28.90079 & -28.54528 & -28.77807 \\
1 & 1067.062 & 822.0434 & $3.07 \mathrm{e}-35$ & $\mathbf{- 5 6 . 8 6 0 7 0}$ & $\mathbf{- 5 3 . 6 6 1 1 3}$ & -55.75621 \\
2 & 1167.728 & $\mathbf{1 0 3 . 5 4 2 1} *$ & $\mathbf{7 . 0 3 e - 3 6 *}$ & $\mathbf{- 5 8 . 9 5 5 9 0 *}$ & -52.91226 & $\mathbf{- 5 6 . 8 6 9 6 4}$ \\
\hline
\end{tabular}

Source: Authors' own compilation using E views

Note: * indicates lag order selected by the criterion

Where, LR stands for sequential modified Likelihood Ratio test statistic; FPE is the Final Prediction Error); AIC denotes the Akaike Information Criterion; HQ stands for Hannan-Quinn information criterion; and SC is for Schwarz Information Criterion. All tests are evaluated at 5\% significance level. Table 1 indicates that the LR, FPE, AIC, and HQ have all selected a VAR system with a maximum lag number of 2 . However, only the SC suggests use a maximum number of lag 1 . Given that the $\mathrm{SC}$ always selects a more parsimonious model, and is most appropriate when handling a small sample size.

Unit Root (Non-Stationarity) Test: The ADF and KPSS stationarity tests were carried out using the equation with an intercept and the model with an intercept and a trend, the outcomes are presented in the Table 2.

Table 2: Unit Root Test- ADF \& KPSS

\begin{tabular}{|c|c|c|c|c|c|c|}
\hline \multirow[t]{2}{*}{$\begin{array}{l}\text { Name of } \\
\text { Variable }\end{array}$} & \multirow[t]{2}{*}{ Model Specification } & \multicolumn{2}{|c|}{$\begin{array}{l}\text { Unit root test } \\
\text { ADF }\end{array}$} & \multicolumn{2}{|l|}{ KPSS } & \multirow[t]{2}{*}{$\begin{array}{l}\text { Order of } \\
\text { Integration }\end{array}$} \\
\hline & & Levels & $\begin{array}{l}\text { First } \\
\text { difference }\end{array}$ & Levels & $\begin{array}{l}\text { First } \\
\text { difference }\end{array}$ & \\
\hline \multirow[t]{2}{*}{ KFr } & Intercept & $\begin{array}{l}-2.1339 \\
(-2.8959)\end{array}$ & $\begin{array}{l}-3.9395^{* *} \\
(-2.8963)\end{array}$ & $\begin{array}{l}0.6452 \\
(0.4630)\end{array}$ & $\begin{array}{l}0.3061^{* *} \\
(0.4630)\end{array}$ & I (1) \\
\hline & Trend \& Intercept & $\begin{array}{l}-1.7951 \\
(-3.4635)\end{array}$ & $\begin{array}{l}-4.0961^{* *} \\
(-3.4620)\end{array}$ & $\begin{array}{l}0.3813 \\
(0.1460)\end{array}$ & $\begin{array}{l}0.0865^{* *} \\
(0.1460)\end{array}$ & I (1) \\
\hline \multirow[t]{2}{*}{$\ln \mathrm{ED}$} & Intercept & $\begin{array}{l}0.4420 \\
(-2.8959)\end{array}$ & $\begin{array}{l}-5.2413^{* *} \\
(-2.8963)\end{array}$ & $\begin{array}{l}2.8439 \\
(0.4630)\end{array}$ & $\begin{array}{l}0.2035^{* *} \\
(0.4630)\end{array}$ & I (1) \\
\hline & Trend \& Intercept & $\begin{array}{l}-3.4189 * \\
(-3.1582)\end{array}$ & & $\begin{array}{l}0.1596^{* * *} \\
(0.2160)\end{array}$ & - & $\mathrm{I}(0)$ \\
\hline \multirow[t]{2}{*}{ CD } & Intercept & $\begin{array}{l}-0.1491 \\
(-2.8959)\end{array}$ & $\begin{array}{l}-5.0505^{* *} \\
(-2.8963)\end{array}$ & $\begin{array}{l}2.6366 \\
(0.4630)\end{array}$ & $\begin{array}{l}0.1257^{* *} \\
(0.4630)\end{array}$ & I (1) \\
\hline & Trend \& Intercept & $\begin{array}{l}-2.9998 \\
(-3.4635)\end{array}$ & $\begin{array}{l}-5.0554^{* *} \\
(-3.4642)\end{array}$ & $\begin{array}{l}0.1542^{* * *} \\
(0.2160)\end{array}$ & - & $\mathrm{I}(0)$ \\
\hline \multirow[t]{2}{*}{$\ln \mathrm{T}$} & Intercept & $\begin{array}{l}-2.2640 \\
(-2.8951)\end{array}$ & $\begin{array}{l}-9.2703^{* *} \\
(-2.8955)\end{array}$ & $\begin{array}{l}1.4405 \\
(0.4630)\end{array}$ & $\begin{array}{l}0.0572^{* *} \\
(0.4630)\end{array}$ & I (1) \\
\hline & Trend \& Intercept & $\begin{array}{l}2.8174 \\
(-3.4623)\end{array}$ & $\begin{array}{l}-9.2221^{* *} \\
(-3.4622)\end{array}$ & $\begin{array}{l}0.0859^{* *} \\
(0.1460)\end{array}$ & - & $\mathrm{I}(0)$ \\
\hline \multirow[t]{2}{*}{$\operatorname{lnGX}$} & Intercept & $\begin{array}{l}-2.4652 \\
(-2.8959)\end{array}$ & $\begin{array}{l}-2.9739^{* *} \\
(-2.5869)\end{array}$ & $\begin{array}{l}0.6741^{* * *} \\
(0.7390)\end{array}$ & - & $\mathrm{I}(0)$ \\
\hline & Trend \& Intercept & $\begin{array}{l}-2.3396 \\
(-3.4635)\end{array}$ & $\begin{array}{l}-3.0336 \\
(-3.4642)\end{array}$ & $\begin{array}{l}0.4120 \\
(0.1460)\end{array}$ & $\begin{array}{l}0.1187^{* *} \\
(0.1460)\end{array}$ & I (1) \\
\hline $\operatorname{lnGD}$ & Intercept & $\begin{array}{l}-0.6155 \\
(-2.8972)\end{array}$ & $\begin{array}{l}-3.2735^{* *} \\
(-2.8972)\end{array}$ & $\begin{array}{l}1.1021 \\
(0.4630)\end{array}$ & $\begin{array}{l}0.0557^{* *} \\
(0.4630)\end{array}$ & I (1) \\
\hline
\end{tabular}




\begin{tabular}{lllllll}
\hline & Trend \& Intercept & -2.6735 & $-3.2357^{*}$ & $0.1503^{* * *}$ & - & I (0) \\
InINF & $(-3.4655)$ & $(-3.1594)$ & $(0.2160)$ & & \\
& Intercept & $-3.1672^{* *}$ & - & 0.8314 & $0.0281^{* *}$ & I (1) \\
& & $(-2.8959)$ & & $(0.4630)$ & $(0.4630)$ & \\
& Trend \& Intercept & $-3.9567^{* *}$ & - & $0.0806^{* *}$ & - & I (0) \\
InFD & $(-3.4635)$ & & $(0.1460)$ & & \\
& Intercept & -1.4326 & $-4.0656^{* *}$ & 2.0378 & $0.1202^{* *}$ & I (1) \\
& & $(-2.8959)$ & $(-2.8963)$ & $(0.4630)$ & $(0.4630)$ & \\
& Trend \& Intercept & -2.4031 & $-4.0397^{* *}$ & 0.3955 & $0.1261^{* *}$ & I (1) \\
& & $(-3.4635)$ & $(-3.4642)$ & $(0.1460)$ & $(0.1460)$ & \\
\hline
\end{tabular}

Sources: Authors' own compilation using E views.

Note: ${ }^{*},{ }^{* *}$, and ${ }^{* * *}$, denotes the rejection of a unit root null hypothesis at the critical values of $10 \%, 5 \%$, and $1 \%$ respectively in instances whereby a variable is stationary in all levels, $* *$ is chosen.

Following the ADF test results from Table 2, it is evident that most of the macroeconomic variables used in this study were non-stationary in level, but stationary after first difference. Confirming these outcomes with a more powerful test, the KPSS unit root test, it can be seen that most variables are still non-stationary in level form however after first difference they all become stationary. This means, other supportive tests should be carried out in order to reach a conclusion. The final conclusion of the order of integration is based on the KPSS unit root test. The mixture in the order of integrations makes the application of the ARDL BT to cointegration approach an appropriate methodology to be applied in this study.

ARDL Cointegration Test Results: Using the automatic selection of lags found in E views, the appropriate number of lags for the ARDL Model was found to be: $(1,1,1,1,1,1,1,1)$. The model's lag selection is based upon the AIC lag selection criteria. Table 3 presents the results as follows:

Table 3: ARDL BT for Cointegration

\begin{tabular}{lllcc}
\hline Variables & \multicolumn{2}{c}{ F-Statistics } & \multicolumn{2}{c}{ Result } \\
\hline$f($ ED, CD, T, GX, GD, INF, FD) & \multicolumn{2}{c}{$102.7930^{* * * * * * *}$ Pesaran } & \multicolumn{2}{c}{ Cointegration } \\
\multicolumn{2}{c}{ Narayan } \\
Critical Value & Lower Bound & Upper Bound & Lower Bound & Upper Bound \\
$1 \%$ & 2.73 & 3.9 & 3.40 & 5.03 \\
$5 \%$ & 2.17 & 3.21 & 2.52 & 3.83 \\
$10 \%$ & 1.92 & 2.89 & 2.15 & 3.30 \\
\hline
\end{tabular}

Source: Authors' own compilation using E views

Note: ${ }^{* * * * * *}$ denotes rejection of null hypothesis of no cointegration at $1 \%, 5 \%$ and $10 \%$ levels of significance respectively.

The, critical values obtained from Narayan (2005) is for 36 observations; Case IV is for restricted constant and no trend $(\mathrm{k}=7)$. Comparing the calculated F-Statistics results from Table 3, with critical values obtained from both Pesaran and Narayan, F-Statistics value is beyond the upper bounds at all levels of significance in both instances. Thus, there is adequate evidence to reject the null hypothesis of no cointegration and conclude that the variable exhibits a long-run equilibrium relationship.

Long-Run Coefficient using ARDL Approach: After establishing the presence of a long-run relationship among the variables, next step was to estimate the marginal effects of each explanatory variable on the explained variable using equation 3 . Table 4 presents the long-run coefficients.

Table 4: ARDL Estimated Long-Run Coefficients $(1,1,1,1,1,1,1,1)$

\begin{tabular}{llll}
\hline Variables & Coefficient & t-Statistic & Prob. \\
\hline $\ln \mathrm{ED}$ & 0.116192 & 0.720824 & 0.4794 \\
$\mathrm{CD}$ & -1.597724 & -2.437320 & 0.0243 \\
$\ln \mathrm{T}$ & -1.052131 & -1.132400 & 0.2709 \\
$\ln \mathrm{GX}$ & 4.125574 & 5.269625 & 0.0000 \\
\hline
\end{tabular}




\begin{tabular}{llll}
\multicolumn{4}{c}{$\begin{array}{c}\text { Journal of Economics and Behavioral Studies (ISSN: 2220-6140) } \\
\text { Vol. 11, No. 4, pp. 18-30, August 2019 }\end{array}$} \\
\hline \hline $\ln \mathrm{GD}$ & & 0.0007 \\
$\ln \mathrm{INF}$ & 0.620453 & 4.010219 & 0.0044 \\
$\ln \mathrm{FD}$ & -0.340596 & -3.209009 & 0.0000 \\
$\mathrm{C}$ & -1.797308 & -7.260408 & 0.0182 \\
\hline
\end{tabular}

Source: Authors' own compilation using E views

Note: * denotes that the variable is significant.

Table 4 reveals that in the long-run, GD (which is the interaction term between government expenditure (GX) and the level of debt stock (CD)) and government expenditure (GX) affect capital flight (KF) positively. The positive effect between GD and capital flight implies that Namibia's capital flight is partially debt-fuelled. This is not surprising given the drastic increases ratio of debt to GDP over the past few years. Currently the debt to GDP ratio stands at $46.3 \%$ which is beyond the established thresh hold of 35\%. Accordance to the debt driven capital flight theory, individuals as well as companies tend to transferring their financial resource abroad when they perceive that the debt being incurred by their government is too huge and it is likely to burden their hard earned capital gains in the nearest future. The positive impact between government expenditure and capital flight support the debt-fuelled hypothesis such that an increase in government expenditure is associated with more debt that subsequently enhances capital flight. On the other hand, an inverse relationship is reported for debt stock (CD), financial deepening (FD) and inflation (INF). The negative effect between the two control variables (Inflation (INF) and Financial Deepening (FD)) and capital flight is in line with the a priori expectations. The negative relationship between financial deepening and capital flight seems to suggest that in the long-run as the Namibian financial sector service provision continues to evolve, individual have little incentives to transfer their financial assets abroad. In addition to that, the fact that the Namibian economy is politically stable, which is an indispensable requirement need to instil the investors' confident in the long-run could serve as an added advantage to reverse capital flight in the country. This means, other supportive tests should be carried out in order to reach a conclusion.

Short-Run Dynamics of Capital Flight in Namibia: The study further analysed the nature and direction of the short-run dynamics of the selected macroeconomic variables by estimating the error correction model (ECM). Under the ECM method, a long-run relationship amongst the variables within the model is ascertained by a negative sign and a significant probability value of the ECM. Equation (4) was used to estimate the general short-run dynamics and the results are provided in Table 5.

Table 5: ARDL Error Correction Model $(1,1,1,1,1,1,1,1)$

\begin{tabular}{llll}
\hline Variables & Coefficient & t-Statistic & Prob. \\
\hline $\mathrm{D}(\mathrm{KF}(-1))$ & 0.849732 & 31.17363 & 0.0000 \\
$\mathrm{D}(\ln \mathrm{ED})$ & -0.098797 & -5.280667 & 0.0001 \\
$\mathrm{D}(\ln \mathrm{ED}(-1))$ & 0.071405 & 3.488864 & 0.0030 \\
$\mathrm{D}(\mathrm{CD})$ & 0.504573 & 4.370885 & 0.0005 \\
$\mathrm{D}(\mathrm{CD}(-1))$ & -0.820777 & -9.321068 & 0.0000 \\
$\mathrm{D}(\ln \mathrm{T})$ & -9.740098 & -24.32920 & 0.0000 \\
$\mathrm{D}(\ln \mathrm{T}(-1))$ & 8.976363 & 31.30012 & 0.0000 \\
$\mathrm{D}(\ln \mathrm{GX})$ & -3.078948 & -11.74497 & 0.0000 \\
$\mathrm{D}(\ln \mathrm{GX}(-1))$ & 3.914416 & 14.06527 & 0.0000 \\
$\mathrm{D}(\ln \mathrm{GD})$ & 0.588054 & 14.27231 & 0.0000 \\
$\mathrm{D}(\ln \mathrm{GD}(-1))$ & -0.419151 & -12.80107 & 0.0000 \\
$\mathrm{D}(\ln \mathrm{INF})$ & -0.162714 & -10.36557 & 0.0000 \\
$\mathrm{D}(\ln \mathrm{INF}(-1))$ & 0.106315 & 8.744519 & 0.0000 \\
$\mathrm{D}(\ln \mathrm{FD})$ & -1.105198 & -10.42583 & 0.0000 \\
$\mathrm{D}(\ln \mathrm{FD}(-1))$ & 1.015238 & 12.90144 & 0.0000 \\
$\mathrm{ECT}(-1)$ & -0.668358 & -2.795108 & 0.0130 \\
$\mathrm{C}$ & -0.005733 & -1.669120 & 0.1145
\end{tabular}

Source: Authors' own compilation using E views Note: * denotes that the variable is significant. 
The results from Table 5 show a negative error correction term of -0.6684 which is statistically significant. This finding simply reaffirms the results of cointegration between the variables used in this study. More precisely, the coefficient of the error correction term indicates that approximately $67 \%$ of the disequilibrium from previous quarter's period of shocks will converge itself back to the long-run equilibrium levels in the current quarter. The short-run result from Table 5 reveal that previous capital flight, previous external debt, previous corporate tax rate, previous government expenditure, current interaction of government expenditure and debt stock, previous inflation and previous financial deepening are jointly associated with an increase in capital flight. The evidence that previous capital flight is positively related to current capital flight is an evidence of habit formation. The fact that previous external debt and current debt stock are associated to capital flight is a sign that capital flight is debt driven, which is in line with the debt-fuelled capital flight theory. In the same vein, the finding that previous corporate tax rate is found to exacerbate capital flight in the shorter horizons. This is because a higher corporate tax rate is an indication that most investment returns accrued to corporate shareholders ends up being eroded off.

This indicates that corporate companies operating in Namibia tend to repatriate their investment funds elsewhere where they have better incentives (such a lower corporate tax rates). On the other hands, the reason why corporate tax rate is negatively related to capital flight in the current period, it is because whenever a policy announcement is passed, its effects are not always felt immediately. Some take a while before their effects are felt in the economy. The finding implies that a contractionary fiscal policy in terms of increased tax rate will be associates with an increase in capital flight of not less than 9 percent. Conversely, present values of external debt, current inflation rates, and the interaction term of past government expenditure and debt stock were found to negatively affect capital flight in the short-run. Likewise, the findings that current financial deepening negatively relates to capital flight is in line with the a priori expectations because of the reasons aforementioned. It is evident that some results obtained the short-run are not consistent with the ones obtained in long-run. Nonetheless, the results obtained with respect to past capital flight are in line with those obtained by other researchers; such as, Al-Fayoumi, AlZoubi and Abuzayed (2012), Ndikumana and Boyce (2003) and Cuddington (1986), but inconsistent with the findings.

Likewise, the finding with regards to current external debt are in harmony with: Muchai and Muchai (2016); Al-Fayoumi, AlZoubi, and Abuzayed (2012). In the light of the above empirical results, there exists sufficient evidence that fiscal policy has largely contributed to capital flight in Namibia. However, the effect of corporate tax rate may be temporary and could be reversed in the long-run given the insignificant inverse relationship. These findings provide useful insight to policy makers on how fiscal policy instruments ought to be handled and managed in order to curb the problem of capital flight in Namibia.

Wald Coefficient Test: The Wald coefficient test is employed to examine and validate the significance of whether or not fiscal policy variables are jointly significant in explaining variations of capital flight in Namibia. The results of these tests are presented in Table 6.

Table 6: Wald Test for Joint Significance of the Fiscal Policy Variables

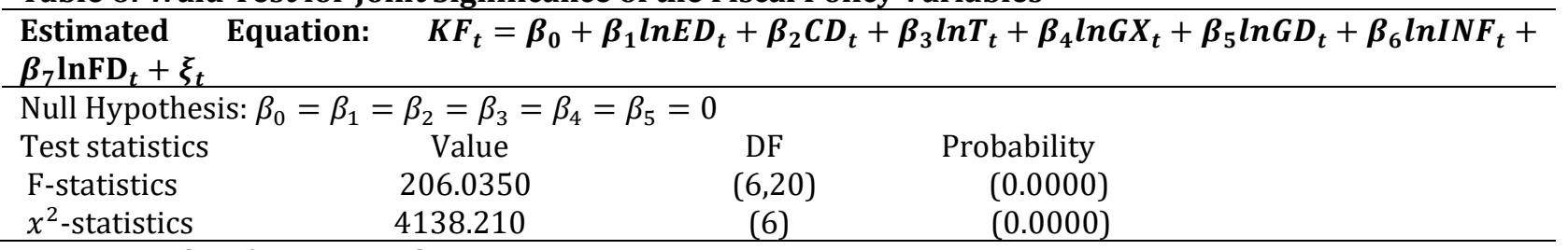

Source: Authors' own compilation using E views

From Table 6, there is strong evidence that fiscal policy variables are jointly significant in determining capital flight in Namibia. 


\section{Diagnostic Tests}

Table 7: Diagnostic Test

\begin{tabular}{|c|c|c|}
\hline White Heteroscedasticity & Chi-square: & $13.47407(0.7039)$ \\
\hline Breusch-Godfrey LM Test & Chi-square: & $1.9599 \quad(0.1029)$ \\
\hline Ramsey RESET Test & F-statistics & $0.0978 \quad(0.7588)$ \\
\hline
\end{tabular}

Source: Authors' own compilation using E views

Results from Table 7 illustrates that the model has passed all essential diagnostic tests. In particular, the Ramsey RESET test indicates that the overall model is correctly specified. The White heteroscedasticity test result refutes the presence of heteroscedasticity. The Breusch-Godfrey LM test further affirms the absence of serial correlation.

Stability Tests: Lastly, the stability test of the long-run parameters combined with the short-run dynamics for the equations is assessed in order to decide whether or not the parameters in the model are stable. This study employed the cumulative sum of recursive residuals (CUSUM) as well as the cumulative sum of recursive residuals of squares (CUSUMSQ) to check for the model's stability. Figure 1 and 2 illustrate the findings as follows:

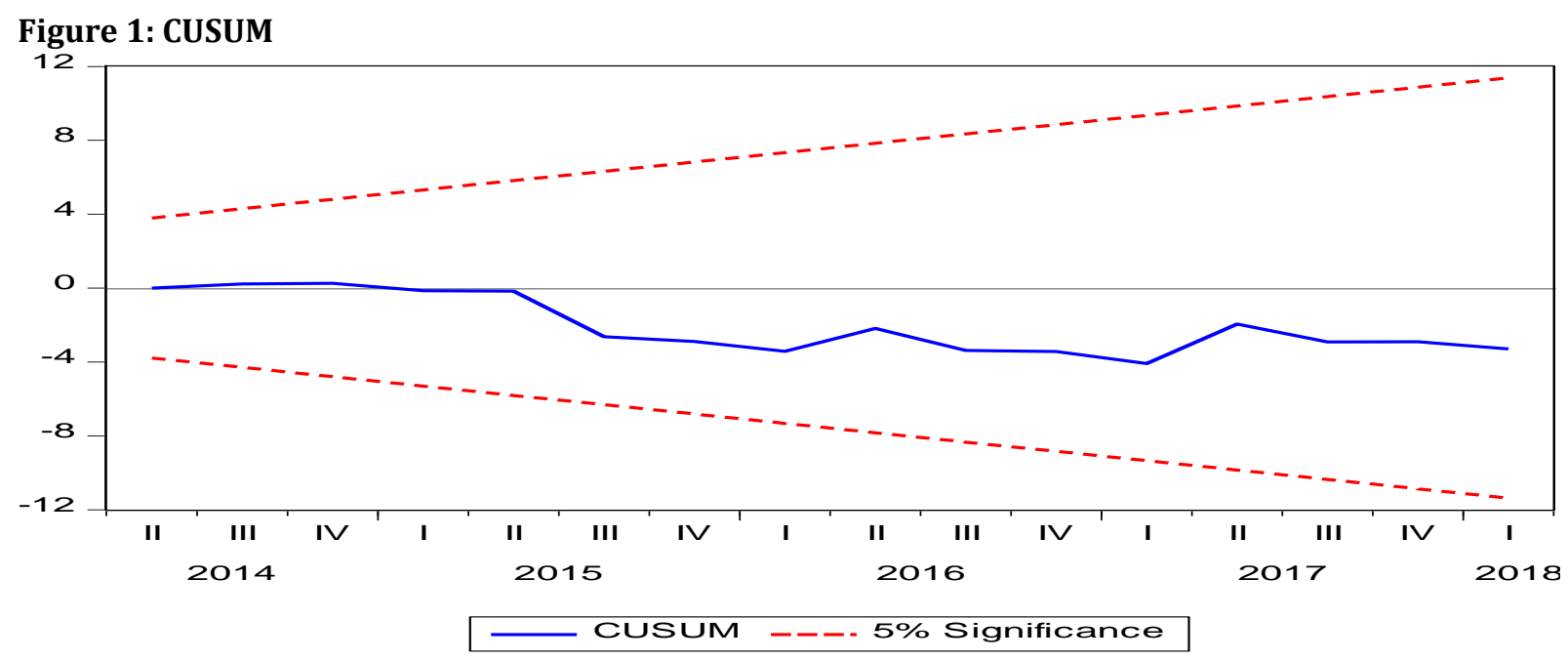

Figure 2: CUSUM

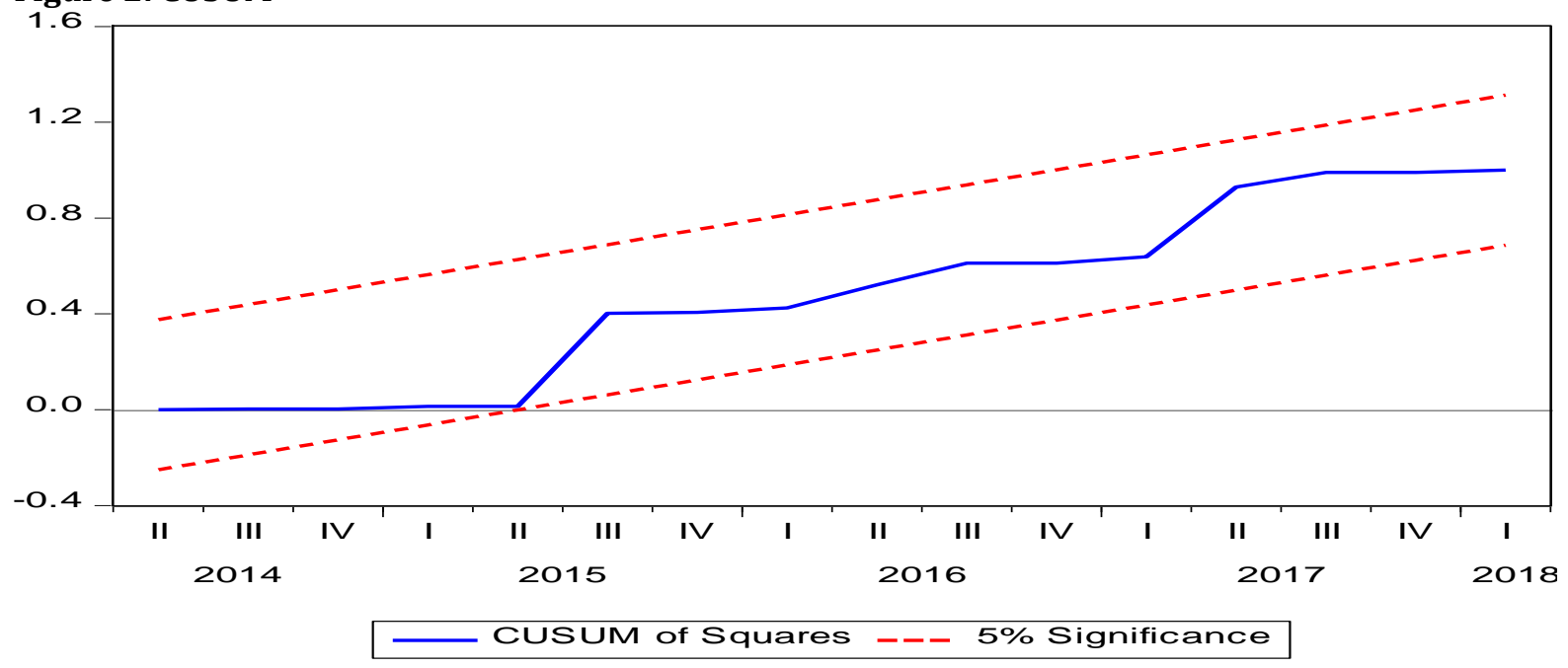


The results from both Figure 1 and Figure 2 suggest that the model used in this study is correctly specified and stable in both plots. This is so because plot of the critical bounds is well within the $5 \%$ levels of significance.

Table 8: Magnitude of Capital Flight in Namibia between Periods 1993-2014 (in N\$ Millions)

\begin{tabular}{|c|c|c|c|c|c|c|}
\hline Year & $\begin{array}{c}\text { (Change in } \\
\text { External Debt) } \\
\Delta \text { ED }\end{array}$ & $\begin{array}{c}\text { (Net Foreign Direct } \\
\text { Investment) } \\
\text { FDI }\end{array}$ & $\begin{array}{c}\text { (Current } \\
\text { Account } \\
\text { Balance) CAB }\end{array}$ & $\begin{array}{c}\text { (Change in } \\
\text { Foreign } \\
\text { Reserves) } \\
\Delta \mathrm{FR} \\
\end{array}$ & $\begin{array}{c}\text { (Capital } \\
\text { Flight) KF }\end{array}$ & $\begin{array}{c}\text { KF as a } \\
\% \text { of } \\
\text { Real GDP }\end{array}$ \\
\hline 2009 & -895.29 & $-6,513.00$ & $-2,423.60$ & $1,115.49$ & $-6,100.18$ & -0.08 \\
\hline 2010 & 59.18 & $-2,072.00$ & $-3,889.90$ & $-3,620.29$ & $5,497.37$ & 0.07 \\
\hline 2011 & $4,231.40$ & $-5,667.00$ & $-5,962.30$ & $4,198.29$ & 328.41 & 0.00 \\
\hline 2012 & $2,291.13$ & $-8,672.00$ & $-7,264.70$ & 323.19 & 560.63 & 0.01 \\
\hline 2013 & $1,718.07$ & $-7,264.00$ & $-9,627.30$ & 980.24 & $3,101.14$ & 0.03 \\
\hline 2014 & 396.76 & $-4,621.00$ & $-13,191.30$ & $-2,182.59$ & $11,149.65$ & 0.11 \\
\hline 2015 & $16,901.20$ & $-10,884.00$ & $-21,065.90$ & $10,050.31$ & $17,032.79$ & 0.16 \\
\hline 2016 & $-3,069.00$ & $-5,138.00$ & $-23,006.10$ & $1,142.89$ & $13,656.21$ & 0.12 \\
\hline 2017 & $1,164.00$ & $-6,927.00$ & $-3,943.90$ & $5,457.00$ & $-7,276.10$ & -0.07 \\
\hline 2018 & $5,730.00$ & $-1,583.00$ & -757.00 & 846.61 & $4,057.39$ & 0.04 \\
\hline Total & $28,527.45$ & $-59,341.00$ & $-91,132.00$ & $18,311.13$ & $42,007.32$ & 0.04 \\
\hline
\end{tabular}

Source: Authors' own compilation

Estimates from table 10 reveal that Namibia lost approximately $\mathrm{N} \$ 42$ billion in 9 years $(2009-2018)$ in the form of capital flight. During the same period, capital flight to GDP ratio was approximately 4\%. Implying that, for every N\$1.00 of annual GDP accumulated by the Namibian economy, private Namibian residents amassed about $\mathrm{N} \$ 0.04$ in the form of external assets. With regards to the interpretations of capital flight, a positive amount of KF implies an unrecorded capital flight since it is a resemblance of private assets accumulated abroad. On the other hand, a negative amount of $\mathrm{KF}$ implies unrecorded reversed capital flight, which is tantamount to a decrease in foreign private assets.

\section{Conclusion and Policy Recommendations}

The main objective of this study was to examine the effects of fiscal policy on capital flight in Namibia using quarterly data from period -2009 - 2018. An econometric analysis using the ADRL BT approach to cointegration was carried out in order to ascertain the role played by fiscal policy in influencing capital flight. The study found that in the long-run capital flight is exacerbated by government expenditure and its interaction with debt stock, whilst financial deepening and inflation are inversely related to capital flight. On the contrary, the short-run results divulge that, past capital flight, previous period tax rates, previous external debt, current debt stock, previous inflation rate, and previous financial deepening plays a significant role in worsening the problem of capital flight. The study also attempted to uncover magnitude of capital flight, and the estimations shows that Namibia lost an enormously an amount to the tune of approximately N $\$ 42$ billion over a period of 9 years. Had these funds stayed in the country, part of it could have been used to steer up more investments and economic development need to uplift the ailing economy, thereby improving the living standard of citizens in the country.

The empirical results from this study seems to insinuate that the magnitude of the capital flight is to a large extent attributed to excessive increase in government expenditure coupled with its debt stock accumulation. The outcomes from this study yields several policy implications deemed for Namibia and other developing economies with similar characteristics to Namibia. Firstly, the fact that the previous external debt and current debt stock in the short-run and the interaction term between government expenditure and debt stock (GD) in the long-run are found to positively affect capital flight validates the idea that capital flight in Namibia is debt- 
fuelled.. Hence, government should pay close attention on how much they borrow and how the borrowed money is utilised. Secondly, the fact that previous tax rates have got a positive effect on capital flight should be taken seriously. The government through the ministry of finance should reconsidering exploring other alternative means of generating revenue instead of overburdening corporation (and the working class) with hefty tax rates which discourages their participation in the economy. The government should continue pursuing policies that helps accelerate the creation of a conducive, economic environment.

This will promote inward investment opportunities, thereby offsetting capital flight. Thirdly, the inverse relationship of previous financial deepening and capita flight entails that there is still room for improvement of the financial sector service provision. Such relaxation will cause the country's financial system to open up, thereby causing it to develop at a faster pace as a result of the benefits that comes with the spirit of competition. This is necessary because many a times the flow of capital is always from the least developed financial markets (Namibia) to a highly developed financial market (say, South Africa). Lastly, there is a need for concerted effort by the government to engage countries believed to have been benefiting from Namibia's capital flight to help combat the issue of capital flight. This is for instance possible if countries agree to establish international tax treaties that could see governments across the world liaising information (especially those linked to financial crimes, i.e., money laundering) which is crucial to curbing capital flight. These actions will no doubt broaden government's revenue base since it will cause it to be in a positions of taxing its local residents as well as those residents who are residing abroad, and holding their financial assets abroad.

\section{References}

Ahmad, B. \& Sahto, Q. D. (2015). Determinants of Capital Flight in Pakistan. IBT Journal of Business Studies, $8(2), 55-64$.

Makochekanwa, A. (2007). An Empirical Investigation of Capital Flight from Zimbabwe (No. 2007-11). University of Pretoria Working Paper. Retrieved from University of Pretoria website: http://www.repository.up.ac.za/

Al-Fayoumi, N. A., AlZoubi, M. S. \& Abuzayed, B. M. (2012). The Determinants of Capital Flight: Evidence from MENA countries. The International Business \& Economics Research Journal (Online), 11(1), 1.

Allum, P., Dwight, L. \& Chen, C. (2008). Namibia: Selected issues and statistical appendix (IMF Country Report No. 08/82). Retrieved from the International Monetary Fund.

Cooper, W. H. \& Hardt, J. P. (2000, March). Russian capital flight, economic reforms, and US interests: An analysis. Congressional Research Service, Library of Congress.

Cuddington, J. T. (1986). Capital flight: Estimates, issues, and explanations. Princeton, NJ: International Finance Section, Department of Economics, Princeton University.

Henry, A. W. (2013). Analysis of the Effects of Capital Flight on Economic Growth: Evidence from Nigerian Economy (1980-2011), Analysis, 5(17).

Hermes, N. \& Lensink, R. (2001). Capital flight and the uncertainty of government policies. Economics letters, 71(3), 377-381.

Le, Q. V. \& Zak, P. J. (2006). Political risk and capital flight. Journal of International Money and Finance, 25(2), 308-329.

Kar, D. \& Spanjers, J. (2014). Illicit Financial Flows from Developing Countries: 2003-2012. Global Financial Integrity Report.

Kollamparambil, U. \& Gumbo, D. (2018). Capital flight in Africa: an analysis of macroeconomic and institutional quality determinants. African Finance Journal, 20(2), 21-44.

Narayan, P. K. (2005). The saving and investment nexus for China: evidence from cointegration tests. Applied economics, 37(17), 1979-1990.

Ndiaye, A. S. \& Siri, A. (2016). Capital flight from Burkina Faso: drivers and impact on tax revenue. African Development Review, 28(S1), 100-112.

Ndikumana, L. \& Boyce, J. K. (2003). Public debts and private assets: explaining capital flight from SubSaharan African countries. World Development, 31(1), 107-130.

Mohamed, S. \& Finnoff, K. (2005). Capital Flight from South Africa, 1980-2000. Capital Flight and Capital Controls in Developing Countries, 85-115. 
Muchai, D. M. \& Muchai, J. (2016). Fiscal policy and capital flight in Kenya. African Development Review, 28, 821.

Ogbokor, C. A. \& Musilika, O. A. (2014). Investigating the relationship between aggregate savings and investment in Namibia: A causality analysis.

Okoli, M. N. (2008). An empirical analysis of the determinants of capital flight and their impact on the Nigerian economy (Doctoral dissertation, University of Technology, Owerri, Nigeria).

Pesaran, M. H., Shin, Y. \& Smith, R. J. (2001). Bounds testing approaches to the analysis of level relationships. Journal of applied econometrics, 16(3), 289-326.

Wujung, V. A. \& Mbella, M. E. (2016). Capital flight and economic development: The experience of Cameroon. Economics, 5(5), $64-72$. 